\title{
Organizational Attractiveness as a predictor of Employee retention
}

\author{
Sanskrity Joseph ${ }^{1}$, Susmriti Sahu ${ }^{1}$, Khan Abrar Uz Zaman Khan ${ }^{2}$ \\ ${ }^{I}$ Institute of Management, Pt. Ravishankar Shukla University, Raipur 492010, India \\ ${ }^{2}$ Psychometrics Laboratory, School of Studies in Psychology, Pt. Ravishankar Shukla University, Raipur \\ 492010, India
}

\begin{abstract}
This study is a piece of empirical research work which aims to examine the prediction effect of organizational attractiveness on employee retention. Following the incidental cum random sampling technique 200 State bank of India (III class) employee were drawn from Chhattisgarh state to serve as participants in the present research work. In the present research work correlational research design was employed. Organizational attractiveness was measured by organizational attractiveness scale (Highhouse et. al., 2003). Employee retention was measured by employee retention questionnaire (Kyndt et. al, 2009). Prediction effect was examining using by hierarchical regression analysis. The result of the present study indicates that in organizational attractiveness emerged as a significant predictor of employee retention. There is sufficient empirical and statistical evidence of the prediction effect of organizational attractiveness on employee retention in state bank of India III class employee.
\end{abstract}

Key words: Organizational attractiveness, Employee Retention, Prediction

\section{Introduction}

Although it has been a major concern for the organization to attract and choose the appropriate talent for their workforce (e.g. Schneider, 1987; Rynes \& Barber, 1990) there is a cut throat competition in the job market globally; scarcity of appropriate talent had lead to lack of desired manpower in the organizations in the present scenario. So it has become a reason for major concern for the organizations to attract the potential talent and to make them to stay in the company. According to the study conducted by Aspiring Minds, namely National Employability Report-Graduates 2013, reveals that 47\% of Indian graduates are unfit to for hiring, therefore it has become a great challenge for Indian organization to attract the right talent and even greater to retain them for longer period of time. Thus it has become fairly important for Indian organization to present themselves as attractive organization in the minds of potential and current employees. High house et al. (2003) describes organizational attractiveness as individuals' affective and attitudinal thoughts about particular companies as potential places to work with. According to Tsai and Yang (2010: 49) organizational attractiveness can be defined as willingness of candidates to accept the employment offer in a particular organization and wish to continue the job in the same organization. Whereas Ehrhart and Ziegert (2005) described organizational attractiveness as consideration of potential applicant to the organization, a good place to work. Berthon et al (2005) defined organizational attractiveness as "the envisioned benefits that a potential employee sees in working for a specific organization". Celani and Singh (2011) related employer branding and organizational attractiveness and claimed that organizational attractiveness increases due to employer branding and organization with positive strong employer brand, with less effort succeed to attract and retain its work force. Albertine W,Weekhout J (2011) defined organizational attractiveness as "the package of organizational characteristics an individual perceives and which determines the thoughts about a particular organization as an employer". There are numerous studies which speak about the relationship of organizational attractiveness with different factors, but this study aims to find the relation between organizational attractiveness and Retention intention of an individual. The trace of earliest research says that Vroom (1966) was the first to draw attention of scholars and professionals towards the attractiveness of any organization as best place to work with, to attract the talent .Vroom used single item measure to judge the perception of potential candidates about the attractiveness of any organization and finally concluded by mentioning that organizational attractiveness is specific in each organization. After few years, Singh (1973) also used a single item measure to access the attractiveness of an organization as an employer, he confined his study to measure the attractiveness of any organization by likelihood of any individual to accept employment offer of that particular organization. Later Fisher, Ilgen, and Hoyer (1979) used multi item scale, this study provided a base for accessing the concept of organizational choice and it established a relation between accessing intention and attractiveness of any organization. In addition to this several studies are available which explains about the perception an individual about the prestige of the company (e.g. Turban et al., 1998; Turban \& Greening, 1996). They presented items to measure the degree to which several organizations are perceived as best place to work by suitable candidates, 
and the extent to which the employees feel proud to be the part of any organization. Further Judge and Cable (1997), and Catanzaro et al. (2010) in their studies have explained organizational attractiveness through likelihood of potential candidate of organizational culture of a particular organization. They explained that the organizational culture that best suits the values and principles of any potential candidate is attractive for him; therefore it is very important for any organization, that its organizational culture should project or reflect the values which seem attractive to the mass of the suitable talent. There is yet a very different approach used by various scholars to describe organizational attractiveness (Turban and Cable, 2003; Caligiuri et al., 2010; Williamson et al., 2010) claim that explained that organizational attractiveness can be explained in terms of organizational reputation. Turban and Cable (2003) says that organizational reputation is significant factor in attracting the right candidate to any organization ,they further say that individual will definitely like to work for a company which a have a good reputation in external market, thus according to them reputation is something that adds to attractiveness of any organization. CSP is yet another concept which has been closely linked with the concept of organizational attractiveness from time to time. Corporate Social Performance (CSP) and Organizational Attractiveness have its specific combinations. According to Wood (2010), CSP has been defined as variegated organizational activity which draws implicit results for employees working within, stakeholders and preferably towards its society. While according to Turban and Greening (1996) CSP not only focuses towards its own employees, stakeholders and surrounding society but also influences the job seeker's perception on organization's work space conditions thus attracting them towards organization. Kim and Park (2011) in their study concluded that potential job seekers are more interested to join firms incorporated in CSP activities and searched out the affect of CSP performances on firm's profit. Organizational attractiveness and its terms with reputation is another concept that regulates the adjustment of an organization with its employees and external stakeholders. Turban and Cable (2003) defined organizational reputation as means to attract suitable work force which draws attention of qualified job seekers to apply for job in any organization thereby adding value to the entity while increasing psychological satisfaction of customers and stakeholders too. It provides a global competitive edge, a prospect future to an organization to rise due to its attractiveness and attract the job seekers to join the applicant pool. According to Robertson, organizational attractiveness offers a positive message in the minds of job seekers regarding better workspace orientation which leads their attraction to apply for the job in an organization. Organizational attractiveness affects the individual persona of employees which induces employee cautious by building a special attachment towards firm thereby being loyal, trust worthy and retention psychology thus resulting in self motivational force which also reflects organizational work culture and growth hence with. Organizational image is another concept; it is a conception which builds the identity of employees with the organization. Organizational image itself serves an important role to fortify its need to attract the best talent pool from competitive market since potential employees and jobseekers prefer to serve an organization which has yielded a worth value image. Brown et al., (2006) in their study associated Reputation with Organizational attractiveness. According to them reputation is something, what internal and external stakeholders perceive about the organization. There are various literature which claim that image of any organization is directly related to its attractiveness, the organization that has a good image in the external market attracts good talent, thus are more attractive. Balmer (2001) gave a brief description about the difference between organizational image and Organizational reputation. According to him, reputation represent the attributes of any organization where as image is related to perception of stakeholders about a particular organization. He further added organizational attractiveness can be estimated by measuring the degree of attraction one feels about any organization. Martin (2005) claims that characteristic features that are specific to any organization which are competitively variegated in activities plays a significant role in attracting cream talent from job market and act as key drivers in recruitment drives. From the review of related literature it is clear that there are various concepts related to Organizational attractiveness but this study aims to analyze: The predicting effect of Organizational Attractiveness on Employee Retention.

\section{Methods}

In the present piece of research, correlational research design was employed. Here, the criterion variable is employee retention, organizational attractiveness is predictive variable Age, Education and Work Experience acted as control variables in this study. Following Incidental cum random sampling 200 employees (class-III) were drawn from different state bank of India in the state of Chhattisgarh to serve as participant in the present research work. Organizational attractiveness was measured by organizational attractiveness scale (Highhouse et. al., 2003). Scale consists of 15-item scale. Responses are obtained on a 5-point Likert scale ranging the score between 1 to 5, it's produced Minimum 15 and maximum 75 score. A higher score indicates higher organizational attractiveness. This measure reported in current research work $\alpha=0.82$ internal consistency reliability. Employee retention was measured by employee retention questionnaire (Kyndt et. al, 2009). Questionnaire consists of 11-item scale. Responses are obtained on a 5-point Likert scale ranging the 
score between 1 to 5 , it's produced Minimum 11 and maximum 55 score. A higher score indicates greater employee retention. This measure reported in current research work $\alpha=0.78$ internal consistency reliability.

\section{Results}

All 200 cases were included for data calculation. Variance inflation factors (VIFs) were examined to detect multicollinearity. A hierarchical multiple regression models were used to examine the effect of organization attractiveness on employee retention. Control variables were entered in model 1; organization attractiveness entered in the final model 2. SPSS version 22.0 was used for data calculation.

Table-1 Hierarchical regression models on the effect of organizational attractiveness on employee retention

\begin{tabular}{|c|c|c|c|c|}
\hline \multirow{2}{*}{ Predictors } & \multicolumn{2}{|c|}{ Model 1} & \multicolumn{2}{|c|}{ Model 2} \\
\hline & $\beta$ & VIF & $\beta$ & VIF \\
\hline$\overline{\text { Age }}$ & $.118^{*}$ & 1.217 & $.116^{*}$ & 1.210 \\
\hline Education & $.218^{* *}$ & 1.341 & $.216^{* *}$ & 1.385 \\
\hline Work Experience & $.325 * *$ & 1.651 & $.321 * *$ & 1.565 \\
\hline Organizational Attractiveness & - & - & $.350 * *$ & 1.123 \\
\hline$\overline{\mathbf{R}^{2}}$ & & .230 & & .355 \\
\hline$\Delta \mathbf{R}^{2}$ & & .230 & & .125 \\
\hline $\mathbf{F}$ & & $=95.235 * *$ & & $=18.072 * *$ \\
\hline
\end{tabular}

$* \mathrm{p}<. \overline{05 ;} \quad * * \mathrm{p}<.01$

A Perusal of table-1 indicates it clearly that, VIF (Variance Inflation Factor) values ranged from 1.123 to 1.651 , which were distant from the 4.0 criteria that may indicate multicollinearity concern (Jang, Chiriboga, Kim, \& Rhew, 2010). In the first model control factors explained $23.00 \%$ of total variance $\left(\mathrm{R}^{2}=.228 ; \mathrm{F}_{(3,196)}=\right.$ 95.235; $\mathrm{p}<0.01)$. Age of the participants was positive associated with employee retention $(.118, \mathrm{p}<0.05)$ with increasing age of participants reported high employee retention. Education (1= High Secondary, $2=$ Graduate, $3=$ Post-Graduate) was positive associate with employee retention $(.218, \mathrm{p}<0.01)$ with increasing level of education of participants reported high employee retention. Work Experiences $(1=<1$ year, $2=1$ to 2 year, $3=2$ to 3 year, $4=3$ to 4 year, $5=>4$ year) was positive related with employee retention $(.325, p<0.01)$. In model-2, organizational attractiveness explained an additional $12.5 \%\left(\Delta \mathrm{F}_{(1,195)}=18.072, \mathrm{p}<0.01\right)$ of the variance. Those participants who perceive higher level of organizational attractiveness $(.350, \mathrm{p}<0.01)$ were more likely to report employee retention.

\section{Implication}

The research can be useful for the Indian banking industry in employing effective practices to increase their attractiveness to ensure retention of its employees. It can also help the organization's improve their attractiveness and gain access to the talent pool, minimize loss of expertise and mange diverse workforce. The findings from the study can provide insights into the extent to which Organizational attractiveness can be used as a tool to attract suitable talent and its effect on employee's decision to stay with the organization. It may also contribute to the limited studies undertaken in the Indian context to understand the reasons that motivate the substantial proportion of employees to stay with their respective organizations. The research was carried out in Chhattisgarh and restricted to the selected banks in the state of Chhattisgarh. The findings of this study are thus based on the attitude and opinion of the employees working in public sector bank (state bank of India) in the selected area of study, which may differ if the studied is carried out different area. The study can further extended to employees working in other public or private sector banks and other parts of the country for a more generalized result with large sample size.

\section{Conclusion}

At present scenario, when there is high scarcity of talent in global job market. It has become an issue of major concern for all the business entity to add best talent to their work force. Lack of suitable talent in the job market has become a reason for crucial crusade for the banks at Chhattisgarh. The expedition to attract and retain the talented staff has stimulated issues regarding best organizational practices. The accessibility of manifold opportunities in budding markets and dearth of quality talent has put forth a pursuit to employers to present themselves diversely to attract quality talent pool towards them. Organizational attractiveness has emerged out to be a positive means in best HR practices provided to an organization which can bridge communication gaps between organizations' existing employees, stakeholders and job seekers. Organizations also need to create a workable environment and work on realistic HR strategies, and publicise the same to cope with emerging competitive environment. Employees always tends to get the best responses from their 
organization, and puts best possible efforts if provided with feasible HR policies beneficial for their growth and future. They get motivated through these best policies provided and shares the experiences providing an image and repute towards their organization building an organizational attractiveness for both the job seekers and stakeholders. Thus it can be said that organizations should continuously care for shaping dimensions towards attractiveness by building milestone strategies through their HR practices to yield the loyalty of existing employees and fetch the quality talent thereby providing a competitive edge to the business.

\section{References}

[1]. Aiman- Smith, L., Bauer, T.N., \& Cable, D.M, (2001), Are You Attracted? Do You Intend to Pursue? A Recruiting PolicyCapturing Study, Journal of Business and Psychology, 16, 219-237.

[2]. Albertine, W. \& Weekhout J. (2011) Employer Branding and its Effect on Organizational Attractiveness via the World Wide Web: Results of quantitative and qualitative studies combined

[3]. Balmer, J.M.T. \& Greyser, S.A. (2002). Managing the Multiple Identities of the Corporation. California Management Review, 44(3), $72-86$.

[4]. Berthon P, et al (2005) Captivating Company: dimensions of attractiveness in employer branding. International Journal of Advertising, 24(2), 151-172

[5]. Brown, T.J., Dacin, P.A., Pratt, M.G. \& Whetten, D.A. (2006). Identity, Intended Image, Construed Image, and Reputation: an Interdisciplinary Framework and Suggested Terminology. Journal of the Academy of Marketing Science, 34, 99-106

[6]. Cable, D. M. \& Judge, T. A. (1994). Pay preferences and job search decisions: A person-organization fit perspective. Personnel Psychology, 47, 317-348.

[7]. Catanzaro, D., Moore, H. \& Marshall, T.R., (2010), "The Impact of Organizational Cultureon Attraction and Recruitment of Job Applicants", Journal of Business and Psychology, 25, 649-662.

[8]. Celani, A. \& Singh, P. (2011) Signalling Theory and applicant attraction outcomes. Personal Review, 40, 222-238.

[9]. Ehrhart, K.H. \& Ziegert, J.C., (2005), “Why Are Individuals Attracted to Organizations?”, Journal of Management, 31, 901-919.

[10]. Fisher, C. D., Ilgen, D. R., \& Hoyer,W. D. (1979). Source credibility, information favorability,and job offer acceptance. Academy of Management Journal, 22, 94-103.

[11]. Highhouse, S., Lievens, F., \& Sinar, E. F., (2003), "Measuring Attraction to Organizations", Educational and Psychological Measurement, 63, 986-1001.

[12]. Highhouse, S., Lievens, F., \& Sinar, E.F., (2003), "Measuring Attraction to Organizations", Educational and Psychological Measurement, 63, 986-1001.

[13]. Jang, Y., Chiriboga, D.A., Kim, G., \& Rhew, S. (2010). Perceived discrimination, sense of control, and depressive symptoms among Korean American older adults. Asian American Journal of Psychology, 1, 129-135.

[14]. Kim, S.Y. \& Park, H., (2011), "Corporate Social Responsibility as an Organizational Attractiveness for Prospective Public Relations Practitioners", Journal of Business Ethics, 120-130.

[15]. Kyndt, E., Dochy, F., Michielsen, M., \& Moeyaert, B. (2009). Employee Retention: Organisational and Personal Perspectives. Vocations and Learning, 2(3), 195-215. doi:10.1007/s12186-009-9024-7

[16]. Martin, G., Beaumont, P., Doig, R.\& pate, J. (2005): Branding: A New Performance Discourse for HR?, European Management Journal, 23,76-88.

[17]. Rynes, S. L. \& Barber, A. E. 1990. Applicant attraction strategies: An organizational perspective. Academy of Management Review, 15, 286-310.

[18]. Schneider, B. 1987. The people make the place. Personnel Psychology, 40, 437-453.

[19]. Singh, R. (1973). Information integration theory applied to expected job attractiveness and satisfaction. Journal of Applied Psychology, 60, 621-623.

[20]. Sokro, E. (2012) Impact of Employer Branding on Employee Attraction and Retention. European Journal of Business and Management, 4, 110-120.

[21]. Tsai, W.C., Yang-Irene, W. F., (2010), Does Image Matter to Different Job Applicants? The influences of corporate image and applicant individual differences on organizational attractiveness, International Journal of Selection and Assessment, 18, 48-63.

[22]. Turban, D. B. \& Keon, T. L., (1993), "Organizational Attractiveness: An Integrationist Perspective", Journal of Applied Psychology, 78, 184-193.

[23]. Turban, D. B., \& Greening, D.W. (1996). Corporate social performance and organizational attractiveness to prospective employees. Academy of Management Journal, 40, 658-672.

[24]. Turban, D.B., Cable, D.M., (2003), "Firm Reputation and Applicant Pool Characteristics", Journal of Organizational Behavior, 24, 733-751.

[25]. Vroom,V. H. (1966).Organizational choice: A study of pre- and post-decision processes. Organizational Behavior and Human Performance, 1, 212-225.

[26]. Williamson, I. O., Lepak, D. P., \& King, J. (2003). The effect of company recruitment web site orientation on individuals perceptions of organizational attractiveness. Journal of Vocational Behavior, 63, 242-263

[27]. Wood, D.J., (2010), "Measuring Corporate Social Performance: A Review”, International Journal of Management Reviews, 50-84. 